\title{
STOIC DEFENCE OF PHYSICIAN-ASSISTED SUICIDE
}

\section{Floris Tomasini ${ }^{1}$}

\begin{abstract}
Rational suicide can be minimally defined as: instrumentally rational, autonomous, due to stable goals and not due to mental illness. One major problem with rational suicide is that it tends toward a technical psychiatric definition, excluding any philosophical explanation of why rational suicide could be ethically justified. In other words, there is a tendency towards an instrumental view of rationality which concentrates on safeguarding the rational means of suicide, rather than fully considering the rational ends of why suicide could be ethically justified in certain special and controlled circumstances. To begin, the plausibility of rational suicide is explored. Following on, the classical stoic idea of rational ends of suicide is then reframed for a more contemporary audience in the socially relevant context of physician-assisted suicide.
\end{abstract}

Key words: rational suicide, stoicism, self-preservation, physician-assisted suicide

\section{Defensa estoica del suicidio asistido por el médico}

Resumen: El suicidio racional puede definirse mínimamente como: racional instrumentalmente, autónomo, debido a metas estables y no a enfermedad mental. Un problema mayor con el suicidio racional es que tiende hacia una definición técnica psiquiátrica, excluyendo cualquiera explicación filosófica sobre su justificación ética. En otras palabras, existe una tendencia hacia una visión instrumental de la racionalidad, porque se concentra en salvaguardar los medios racionales de suicidio, más que en considerar plenamente los fines racionales de por qué el suicidio podría ser éticamente justificado en ciertas circunstancias especiales y controladas. Para comenzar, se explora la posibilidad de suicidio racional. Luego, la idea estoica clásica de los fines racionales del suicidio es reformulada para una audiencia más contemporánea, en el contexto socialmente relevante de suicidio asistido por el médico.

Palabras clave: suicidio racional, estoicismo, auto preservación, suicidio asistido por el médico

\section{Defesa estoica do suicídio assistido por médico}

Resumo: Suicídio racional pode ser minimamente definido como: instrumentalmente racional, autônomo, causado por objetivos estáveis e não derivado de doença mental. Um importante problema com o suicídio racional é a sua tendência de uma definição técnica psiquiátrica, excluindo qualquer explicação filosófica do porquê que o suicídio racional poderia ser eticamente justificado. Em outras palavras, há uma tendência do ponto de vista instrumental de racionalidade que concentra sob salvaguardas os meios racionais de suicídio, em vez de considerar totalmente as finalidades racionais pelas quais o suicídio poderia ser eticamente justificado em certas circunstâncias, especiais e controladas. Para começar, a plausibilidade do suicídio racional é explorada. Em seguida, a clássica ideia estoica dos fins racionais do suicídio é, então reformulada para um público mais contemporâneo num contexto socialmente relevante do suicídio assistido por médico.

Palavras-chave: suicídio racional, estoicismo, autopreservação, suicídio medicamente assistido

\footnotetext{
${ }^{1}$ School of Archaeology and Ancient History, University of Leicester, UK

Correspondence: ft59@leicester.ac.uk
} 


\section{Historical background}

Our attitude and understanding of suicide has dramatically changed over time. Although it is unrealistic to chart a detailed history of suicide, it is possible to understand some of the broader shi$\mathrm{fts}$ in perspective that contest the rationality and morality of suicide. There are three broad constituencies of debate around suicide: theological, psychiatric and philosophical.

The prevailing view against suicide arises out of the theological constituency of debate and the idea that all life is sacrosanct. It has deep roots in Judeo-Christian theology and philosophy. In Aquinas' view, for example, suicide is wrong because only God can take our lives away. Also, he believes the act of suicide is contrary to $\mathrm{Na}$ ture(1). Suicide is considered to be self-murder and a terrible sin that has deep historical roots. For example, Catholics still debate whether the soul of a suicide will be denied salvation in the after-life by being sent to purgatory. Furthermore, the sin of suicide was considered to be heinous crime; since as recently as 1860 attempted suicide was punishable in England by death. From 1917 to 1983 , the church's Canon Law said that 'those who killed themselves of a deliberate purpose' were to be deprived of ecclesiastical burial. This provision was dropped from the revised Code of Canon Law promulgated by Pope John Paul II in 1983, which is still the current norm. However, 'grave psychological disturbances, anguish, or grave fear of hardship, suffering, or torture can diminish the responsibility of the one committing suicide'.

\section{Overview of approach and method}

The contemporary debate over suicide has shifted away from theology to psychiatry and philosophy. The main objective of this paper is to defend rational suicide in the context of physician-assisted suicide.

Before this is possible it is necessary to outline the methodology of the study undertaken and to preview the logical sequence of the argument and results as it unfolds in the text. There are three parts to the argument, which characterise three distinctive approaches or methods. The first part of the argument is largely a critical review of whether rational suicide is at all possible. Some commentators have tended to criticise the plausibility of the notion of rational suicide on the grounds that it is: conceptually unintelligible; morally impermissible and; a sign of mental illness. The methodology behind the first third of the paper is to present a critical review of the negative case against the plausibility of rational suicide. The logical sequence of the negative case against rational suicide is based on a philosophical discussion and evaluation of the following questions:

(1) Is suicide intelligible (or conceptually rational)?

(2) Is suicide ever a morally permissible act (or morally rational)?

(3) Can suicide be competently chosen (or mentally rational)?

Having dismissed a negative case against the plausibility of rational suicide, a positive and more persuasive case is made for why rational suicide should be taken seriously in the modern context of physician-assisted suicide. In order to do this, the methodology reverts from critical analysis (of previous writers on the subject) to a more original conceptual analysis of a classical stoic defence of rational suicide, which is then reframed as a neo-stoic perspective on physician-assisted suicide. The logical sequence of this argument is as follows:

(4) Rational suicide from a classical stoic perspective

(5) A neo-stoic perspective on rational suicide in the context of physician-assisted death

Finally to look at the plausibility of the positive case for rational suicide, the argument ends with a methodology that involves 'empirical philosophy', that is an empirical assessment of the rationality of physician-assisted suicide in an institutional setting (the discussion of two case studies at Dignitas). By way of conclusion, there is a short evaluation of the meaning and importance of the study as well the limitations and implications for future research. 
That is,

(6) Case studies in physician-assisted rational suicide

(7) Conclusion

\section{Is rational suicide a plausible notion?}

(1) Is rational suicide intelligible?

Suicide is taken from the Latin sui meaning of 'oneself' and cidium meaning to 'slay or kill'. However, the very intelligibility of self-slaying is questionable without prior cause, since suicide is, generally, not chosen for its own sake. It is fairly unintelligible to 'wish to be dead' for no reason. Suicide is intelligible if it is understood as having an antecedent cause, often in respect to relief from certain kinds of physical pain or psychological anguish(2). Whereas, suicide, commonly understood - as a relief from physical pain and psychological anguish - may have an intelligible cause, it may still not be a rational act. Whilst the cause of someone committing suicide, from a third person perspective, may be intelligible, the act itself may seem insufficiently rational by virtue of the fact that it stems from mentally incompetent decision-making. In other words, most suicide attempts are made by people who are either, mentally ill or, are under enough mental duress, so as not to act in their best (long-term) interests.

Devine presumes that there is no after-life and that we are annihilated by death. Because of our presumed annihilation, Devine argues that death is un-experiencable and therefore any outcome the cessation of pain or psychological anguish, for example - is unexperiencable and unknowable. Furthermore, since it is Devine's view that the precondition of a rational choice is that one must know what one is choosing'( 3 ), it is not rational to kill oneself unless one has full knowledge of what the alternatives are.

Philip Devine's argument is taken to task by Mayo(4). What follows is a short summary of Devine's argument and Mayo's criticisms of it.

There are some serious problems with this view, according to Mayo. First, the presumption that death is annihilation and cannot be experienced is questionable. Some might refer to religious belief in the after-life or 'near-death' experiences to question the unexperiencable nature of death. Even if we grant Devine his presumption that death cannot be experienced it still seems suspect to equate the unexperiencable with the unknowable: following Mayo, 'if we have a good reason to believe that death is annihilation, it is difficult to understand what more needs to be known about it before it can be said to be known'(4:151).

Finally, according to Mayo, Devine seems to be functioning with a form of 'rational choice' where one must have complete knowledge of alternatives. He is, therefore, operating with a standard of rationality that is difficult to attain in any practical sense. In everyday life we routinely operate on the basis of imperfect knowledge, rationally choosing between an unknown and a known evil. So, while it may not be rational to opt for death as an unknown for its own sake, it maybe rational to gamble on the uncertainty of death, when the outcome of suicide is to end a life that is experienced as incontrovertibly hopeless.

By way of a summary: first, the unexperiencable nature of death as an outcome of suicide does not rule out, tout court, its rational sense in a life experienced as hopeless. And second, while suicidal ideation is intelligible, it is, more often than not, carried out by mentally incompetent persons who are not acting in respect to their long-term values and interests. Therefore, the intelligibility of suicide does not fully secure its rationality as either a morally acceptable act or, as competently chosen one.

(2) Is suicide ever morally permissible?

Another fundamental issue concerns the moral permissibility of the suicidal act. Some argue that suicide is morally irrational because it violates a fundamental view that human life is sacrosanct. This view originates in a deontological perspective on morality which holds on to the idea of sanctity of life: human life is intrinsically and inherently valuable, our duty being to honour and preserve ourselves and others no matter what $(2,5)$.

There are a number of difficulties with this kind of view. 
First, the intrinsic value of a life is independent of extrinsic criteria on which the quality of a life may be judged e.g. health and happiness. Any life, therefore, is intrinsically valuable regardless of what kind of life it is and what sort of suffering is endured. Singer cited in the Stanford Encyclopaedia of Philosophy(5) argues that this view misplaces the value of what it is to be living a life. For Singer, extrinsic criteria, like quality of life, are indicators of the value of a life lived. From this perspective, suicide may be morally permissible, if the quality of a life is chronically low and is likely to remain so in the future e.g. in the case of a terminal illness.

Second, it is perfectly possible to value the sanctity of life and still commit suicide. Indeed, Dworkin (1993) cited in Stanford Encyclopaedia of Philosophy admits 'that those who engage in suicidal behaviour, when the future promises to be extraordinarily bleak, do not necessarily exhibit insufficient regard for the sanctity of life' (5:11).

Finally there are even some of those who accept 'the sanctity of life' principle and agree that suicide may affirm life's value if the agent's future prospects are bleak. For some of these commentators like Cholbi $(2,6)$ it might be morally rational to reject a life that misses certain essential qualities for a dignified human life. Cholbi's goes some way to meet the stoic case for rational suicide that follows.

In sum, it does seem that there is a morally rational case for suicide, but only if the agents quality of life is particularly poor and hopeless. Crucially this cannot be secured unless suicide is acted upon by a mentally competent agent.

(3) Can suicide be a mentally competent decision?

Suicide is the main cause of premature death amongst people with mental illness. It is estimated that $10 \%$ of people with mental illness suicide within the first 10 years of receiving their diagnosis. Suicide is a more common cause of death among people with schizophrenia and mood disorders such as bipolar disorder and depression, compared to the general population. People with personality disorders and disorders of addiction also have higher rates of suicide than the general population $^{2}$.

Mental illness significantly impairs rational choice. The way rationality is impaired depends largely on the nature of the mental illness suffered. So, according to Brandt(2) cited in the Stanford Encyclopaedia of Philosophy, a clinically depressed person will have difficulty in projecting himself, beyond his present frame of mind, to take into account his values and preferences.

Since there is a strong correlation between suicide and mental illness it is unsurprising that there are many contemporary critics arguing against the possibility of rational suicide. For example, many psychiatrists see suicide as inherently irrational because suicidal ideation is indicative of some underlying form of mental illness or disorder.

Just because there is a strong correlation between suicide and mental illness does not mean that all suicidal behaviour can be explained away on the basis of people having mental illness. Indeed, some psychiatrists feel a need to distinguish between those suicidal people who commit suicide because they are temporarily mentally incompetent due to a disturbed state of mind, and a much smaller group of mentally competent people who commit rational suicide after a realistic appraisal of their long-term situation. For example Mayo(4:147-149) reviews the approach of the psychiatrist Jerome Motto in this regard. Mayo's argument about Motto's approach is worth summarising in respect of rational suicide as competently chosen suicide.

As a practising psychiatrist, Motto's chief concern is when it is and when it is not appropriate to intervene to prevent suicide. For Motto the notion of rational or irrational suicide bites at the point of suicidal ideation in a clinical setting. Motto introduces two conditions for rational suicidal ideation. First, it must conform to rational beliefs about options and consequences of the decision to suicide. This screens out irrational suicide on the basis of unrealistic beliefs, for example, 'I will never get over my feelings for the lover who rejected me'(4:147). Second, Motto addresses the notion of irrational suicide by screening out

${ }^{2}$ Suicide line. Available from: http://www.suicideline.org.au/ 
decisions based on transitory desires, which run counter to a person's more fundamental values. This deals with many suicidal desires we may impulsively act on when life might not be going so well for us, forgetting that emotional pain is often transitory.

In sum, there are some subtleties of meaning that need to be established between mental incompetence as allied to mental illness and mental incompetence in respect to sound clinical decisionmaking. That is, suicidal ideation is indicative of an underlying mental illness which, by definition is non-rational. However, there are some, like Motto, who believe that suicide maybe rational, if a patient's decision is based on realistic beliefs and in accordance with their long-term values. Interestingly from this perspective, mental incompetence may not be synonymous with mental illness, since the rationality of decision-making is more about good judgment, than any underlying mental health issue.

(4) Rational suicide from a classical stoic perspective

Sellars argues that the foundation of stoic ethics lies in the desire or drive that human and non-human animals have for self-preservation (oikeiōsis) (7). According to Sellars, the ends that contribute to preservation of non-rational animals are: water, food, shelter, etc. For a rational adult human being, however, to survive as rational human animals and not merely as an animal per se, we need pursue those things that preserve our rationality as well as our body. In short, we need to preserve the rationality of our souls as well as the biology of our body's(7:108). By way of an example, Sellars paraphrases Epictetus:

'If a tyrant threatened to kill a stoic, if the stoic did not agree to do certain things he found deeply objectionable, then, in order to secure his selfpreservation, the stoic would have to stand up to the tyrant, even if it meant the loss of his own life' (7:109).

If one breaks down what rational self-preservation amounts to from a classical stoic perspective, it involves three key elements:
An unavoidable conflict. usually brought about by a tyrannical dictator who forced a stoic to sacrifice his values in exchange for his life. In terms of rational self-preservation, in order to preserve the virtue of one's soul, it was sometimes necessary to die honourably by sacrificing one's biological existence.

An intrinsic appreciation of intrinsic human ends over extrinsic needs: the virtuous soul is intrinsically essential to rational life in comparison to bare/ biological life (which supports but does not hold our virtue).

A maximal notion of the good life: classical stoic suicides tended to be honourable, if not heroic, attempting to preserve the perfectibility of a virtuous existence.

Having outlined the classical case for rational suicide, it is necessary to see how such stoicism may be contextualised in a modern context.

(5) A neo-stoic perspective on rational suicide in the context of physician-assisted death

Mayo is a philosopher who has made connections between stoicism, rational suicide, mental competence and voluntary euthanasia. Mayo begins by quoting Seneca: '...It is not of dying earlier or later, but of dying well or ill. And dying well means escape from the danger of living ill' (4:143). In doing so, he aligns himself to a general stoic position. That is, it is sometimes rational to commit suicide for 'good reasons', 'in keeping with the agent's fundamental interests'(4). Mayo goes on to explore this in a more contemporary context, reviewing the argument from more of a psychiatric, rather than philosophical, point of view. From psychiatry he argues that suicide can be rational if it is competently chosen; by that he means if it is a decision based on realistic beliefs aligned to one's long-term values. He also makes the point that stoicism was at the heart of those early campaigners of the British Voluntary Euthanasia Society who in 1969 were narrowly defeated in their attempt to legalise active voluntary euthanasia(4:149). While Mayo's paper is a thoughtful and excellent critical review of the concept of rational suicide from a number of different constituencies of debate, this paper looks at rational 
suicide from a more in-depth philosophical and stoic point of view, within the narrower context of physician-assisted suicide.

Before going on, it is important to distinguish rational suicide from regular suicide. In simple terms, regular suicide may be rationally intelligible, but it is not a rationally competent decision based on an appreciation of intrinsic human ends. Rational suicide per se is not only competently chosen but also aligns to long-term values and interests that are in accord with a notion of a good life, even if, in the case of physician-assisted suicide this is understood in minimal rather than maximal sense.

Interestingly the classical stoic perspective on rational suicide: (a) an unavoidable conflict (b) an intrinsic appreciation of human ends (c) a notion of the good life, repeat with a difference, in the more contemporary context of physician-assisted suicide.

For example, the most compelling context for stoic (rational) suicide is in the case of terminal and/or chronic illness. Here a medicalised death can sometimes throw up an unavoidable conflict between prematurely ending a human life with dignity on the one hand and the technical capacity to prolong bare biological life on the other. In such cases, in order to affirm the preservation of our rational self, we may have to sacrifice our biological self prematurely.

Furthermore, a key difference between the classical stoic and modern stoic has to do with the 'form of life' (8) in which the preservation of longterm values is understood. An ideal rational suicide in the context of a medicalised death secures what is essential to a minimal rather than a maximal form of human flourishing. In other words, the neo-stoic attempt toward rational suicide may provide a context for a physician-assisted suicide where there is a desire to preserve a minimal sense of a good human life with recognizable and intrinsically valuable human ends. The minimal good of self-preservation is not the maximal notion of the perfectibility of the rational soul (as in classical stoicism), but the self-preservation of a minimal good in terms of 'care of the self'. Minimal self-preservation of human flourishing can be thought of in terms of the 'care of the self' rather than 'care of the soul' and, in the context of physician-assisted suicide, can be understood to be about preserving the intrinsic value of the autonomy, quality and the purposefulness of our humanity at the end of life.

Having outlined how neo-stoicism may be used to justify the rational suicide of terminally ill patients, it is important to have some understanding of the physician-assisted context, in which this can take place.

Some commentators draw a distinction between active voluntary euthanasia and physician-assisted suicide, arguing that the latter is an attempt to stop short at the physician 'bringing-about the death of patient'. In this way professional agency is carefully restricted to a more passive role of safeguarding the rationality of suicidal ideation and the patient's true self determination to follow through with the act of suicide. Rational suicide cannot simply be equated to physician-assisted suicide, unless the physician has carried out their duty of care to the patient; making sure that their choice to suicide, is at least mentally competent.

Interestingly this is exemplified by the Swiss organisation Dignitas who are the only organisation that assist 'suicide tourists' in their desire for a rational suicide ${ }^{3}$. It is the client that: initiates the request for suicide; demonstrates their rational self-determination to responsibly carry through suicide without harm and interference from others and; activates and controls the means and timing of their own death. Nevertheless, there is much debate about whether Dignitas always secures a 'good death' in terms of minimal notion of human flourishing. Physician-assisted suicide is just one form of rational suicide and cannot be assumed to be rational unless it really is freely chosen by a mentally competent patient who, in a sense, is 'forced' to choose a dignified human end in the face of a terminal illness that necessarily robs them of their dignity. To avoid a rogue or irrational physician-assisted suicide, the physician needs to make sure that the patient is making a voluntary and mentally competent choice to die.

\footnotetext{
3 In The Guardian newspaper. Available at http://www.guardian. co.uk/society/2009/nov/18/assisted-suicide-dignitas-house (Accessed 20th of march 2013).
} 
In addition medical doctors need to rely on an objective medical prognosis where there is clarity about the fact that minimal expectations of what constitutes the preservation of a good human life will definitely be outstripped by the course of disease.

Crucially if we are to have a thick and rich notion of rational suicide, we need more than just a set of technical reasons, why it is a good idea. The philosophers Pilpel and Amsel have recently criticised rational suicide on these grounds, arguing that technically rational suicides, can still be a 'bad mistake'. They argue that many proponents of rational suicide 'out of a concern for autonomy and self-determination, are loath to claim that people's choice of suicide is wrong unless there is something technically wrong with their reasoning'(1: 111-123).

In short to have a robust view of rational suicide in the context of physician-assisted suicide we need a moral as well as technical rational. In other words, rational suicide is rational if it is:

An instrumentally rational choice: where rational self-preservation involves making a mentally competent choice based on their realistic beliefs and their long-term values.

An intrinsically rational choice: where a person making a decision to suicide has the moral insight to preserve a minimal notion of human flourishing in spite of the medical promise of life stripped to bare biological function.

(6) Case studies in physician-assisted rational suicide

Having provided a theoretical outline of a stoic defence of rational suicide in the context of physician-assisted suicide, it is worth doing a little 'empirical philosophy' to illustrate the plausibility of the case.

Before illustrating some of what has been discussed in neo-stoic terms, it is important to point out that rationally motivated physician-assisted suicide should never be morally obligatory. That is, we can only realistically expect medical professionals to offer their assent and assistance in our desire to die with dignity if they share some of our fundamental values on the intrinsic worth of a human life. This distinction can be illustrated through two case studies from the documentary 'The Suicide Tourist'.

The first case study concerns a suicide pact.

George and Betty Coumbias entered into a suicide pact when George's health seriously deteriorated after he'd had three heart attacks. Because George's life-time partner, Betty, could and would not live without her husband, they approached Dignitas in Switzerland to request assistance with a double suicide. What made the case particularly controversial (even for the most liberal interpretation of rational suicide) was that Betty Coumbias had no significant health problems.

Neither Betty nor George had presented any obvious technical reasons why their request for physician-assisted suicide should be denied. They both entered into a stable and deliberate decision to end their lives (George and Betty had entered a suicide pact long before either one of them had become ill and now that George was gravely ill, Betty could not contemplate a life without him). They were not mentally ill (they might have been in a heavily co-dependent relationship, but neither were obviously mentally ill) and they had not neglected their responsibility to others (both their daughters had been informed and supported them in their decision). In short, some might argue that the couple's choice may have been perceived and defended as the best possible decision for them, given their particular circumstances.

It is difficult, in the case of Betty, to shake off the intuition that she was throwing her life away for reasons that are not good enough.

From the perspective of a physician, it is an anathema to assist in the suicide of a patient who is not in a hopeless medical condition. While George is gravely ill, Betty is perfectly healthy and therefore helping her commit suicide is an obvious affront to the Hippocratic Oath.

Betty is not obviously mentally ill. However, her

\footnotetext{
${ }^{4}$ The Suicide Tourist. 2010, directed by Zaritsky, J., Canada: CTV Television.
} 
mental competence is doubtful given her deeply co-dependent relationship with her husband. In this sense, it might be argued, that her inability to even consider continuing her life without her husband at her side is not rational. Furthermore, it is unclear what the urgency for a suicide pact is when she would not have to give up the option of killing herself later on if she indeed found life without her husband to be unbearable.

The clinical decision-making in this case is highly contestable; that is, while Betty Coumbias was not obviously mentally ill she still may have been mentally incompetent. As argued elsewhere, mental illness and mental incompetence are not necessarily synonymous. In Betty's case the fact that she wasn't mentally ill did not necessarily guarantee her mental competence.

It is interesting that the director of Dignitas, Ludwig Manelli, initially supported the couple's request for consideration of physician-assisted suicide - even though the request was finally turned down by the attending physician, who under pressure from the Swiss authorities, refused to give his consent. Manelli's justification was that it (suicide) should always be the decision of the individual', providing there is no obvious technical reason for the request to be denied.

Manelli's point of view is based on the thin account of what is a technically justifiable idea of a good death. This leads to disturbing libertarian relativism. That is, there is little point in medical professionals acting as gatekeepers, preventing non-rational assisted suicides, if rational suicide is merely permission to assist those technically sane individuals who can weigh up the pros and cons of continued life, and then decide in favour of death. This leaves the door open for suicide on demand; a possible choice for anyone who is autonomous, without a mental illness and reasonably responsible, but perceives, for one specious reason or another, their life turning out badly.

From a psychiatrist like Jerome Motto's point of view, it is unlikely that Betty's decision to enter into a suicide pact with her husband George was competent. Motto provides a thicker and richer account as to what constitutes a clinically good reason to entertain rational suicide. From his point of view, it might be argued that Betty's incompetence arose from the fact that she could not even entertain the possibility that she might be able to create a meaningful life in the absence of her husband, or that she would not be giving up the option of killing herself later on.

Concentrating on instrumental technical reasons alone for justification of rational suicide is, in the author's view, insufficient explanation as to why rational suicide may or may not be a good idea. So, even if we follow the more responsible psychiatrist, Motto (whose position gives a reason to suggest why Betty Coumbias may not be mentally competent for physician-assisted suicide), it still begs certain fundamental philosophical questions as to why Betty killing herself would be bad mistake.

Betty's intransigence at not being able to imagine a meaningful or happy life without her husband is a mentally incompetent decision. However, that mental incompetence stems from her failure to recognise the intrinsic value of her life. That is, Betty's suicide would not have preserved the intrinsic worth of a life thrown into stark relief by an unavoidable conflict between a minimally worthwhile human flourishing on the one hand and bare biological life on the other. Betty does not have a terminal illness, she is relatively healthy. Moreover her life is not psychologically hopeless; she may still live a meaningful and happy life after her husband dies, alone or with someone else. In sum, her suicide would not have been rational in a more philosophically stoic sense.

The second case concerns a person with a terminal illness.

This case followed Craig Ewart a 59 year old retired professor who approached Dignitas for an assisted suicide. He had a terminal disease called Amyotrophic Lateral Sclerosis (ALS is a form of Motor Neuron Disease). ALS attacks nerves and muscles so that sufferers progressively lose function: the ability to stand, walk, get in and out of bed on their own, use hands and arms and eventually breathe (unassisted) and communicate.

Ewart's request for assisted suicide was approved by Dignitas. He ended his life by determining the 
place and time of his death in Switzerland and voluntarily accepting a liquid sedative (before he lost the ability to swallow) that would end his life after he disconnected himself from his artificial breathing apparatus. Craig's choice was instrumentally rational in all the usual senses: it was stable and considered choice (Craig had made the choice, with the help of his wife and family, well before ALS became acute); it was a competent choice (Craig's mental health was good, he was still enjoying life and not depressed); it was responsible to others (he had taken into account how his illness was impacting on his family and discussed that he and they would be better off if he committed suicide); it was the best choice given his circumstances (ALS is progressive terminal disease, where there is no guarantee of not suffering).

In his own words:

"Most statements that you read about the disease are most people have a peaceful death. That's fine for most people, but what if I am the one that doesn't have a peaceful death? What might be peaceful from the outside does not necessarily reflect the internal state of that person. Let's face it when you are completely paralysed you can't talk, you can't move your arms, your eyes, anything, how do you let somebody know you are suffering? ... At this point I've got two choices. Either I go with it or I say you know what I'm too scared right now I don't want to do it. If I go with it, I die, as I know I must soon die, at some point. If I don't go through with it my choice is to essentially suffer and to inflict suffering on my family and then die, possibly, in a way that is considerably more stressful and painful than this way. I've got death and I've got death with suffering"s.

Craig's choice is not only instrumentally rational in all the usual senses, it is also substantively rational. It is substantively (or philosophically) rational because he recognises the unavoidable conflict' between the distinct possibility of 'death and death with suffering' ${ }^{6}$. Moreover, there are some terminal diseases, like ALS, where our animality outstrips our capacity to preserve what we value

\footnotetext{
${ }^{5}$ Ibid., transcription of Greg Ewart.

${ }^{6}$ Ibid., Greg Ewart.
}

about living life as a human being. When Craig was diagnosed with ALS and started to contemplate suicide he recognised the tension between human life and bare life: 'you can only watch so much of yourself drain away and say, at some point, this is an empty shell' 7 . Therefore, for the sake of preserving his humanity, it makes sense, in this more substantive stoic sense, for Craig to have seriously contemplated ending his life prematurely. Finally there is evidence that Craig understood and appreciated joy, which was essentially about life despite the progression of the disease: 'I still enjoy living enough that I'd like to continue. But the thing is I really can't, I am not tired of living I am tired of the disease ${ }^{8}$. Craig, right up until his very end, still appreciated the intrinsic goodness of his life as a human being but realised that there was no way of preserving this without, ironically, committing suicide and putting a stop to a disease that was robbing him of his humanity. His happiness had to do with the appreciation of his human capacity to still enjoy life while he could. Likewise his fear of suffering had to do with a fundamental fear that this could no longer be humanly communicated, understood and, therefore relieved.

\section{(7) Conclusion}

Having made a special case for rational as opposed to regular or irrational suicide, it has been argued that rational suicide is particularly relevant when considering physician-assisted suicide. In arguing for the connection between the two there has been attempt to offer a stoic defence of rational suicide. In doing so, it is argued that for physician-assisted suicide to be fully rational it must preserve both competent decision-making to rational suicide as well safeguarding a shared sense of the intrinsic value of what makes human beings 'human' at the end of life.

The originality and importance of the paper lies in the fulsome nature of the neo-stoic defence of rational suicide in physician-assisted death. Whilst Mayo is the first to make the connection, this paper makes clear the classical stoical roots of this argument and how it maybe reframed in the

\footnotetext{
${ }^{7}$ Ibid., Greg Ewart.

${ }^{8}$ Ibid., Greg Ewart.
} 
context of physician-assisted suicide.

This said there are limitations to the results of this study. That is, whilst it is perfectly possible to present a cohesive and persuasive philosophical argument for physician-assisted rational suicide, it is quite another matter to safely secure rational suicide in an institutionally robust setting. As previously argued, Dignitas does not always inspire confidence in securing the neo-stoic ideal of rational suicide (as evidenced by Coumbias case). As such, the implications for future research are more practical than philosophical: one might, for example, study how to secure rationally physician-assisted suicide in a robust institutional setting or, one could look into devising a robust legal framework.

\section{Acknowledgements}

I would like to thank the Wellcome Trust in the UK for sponsoring and supporting this research.

\section{References}

1. Pilpel A, Amsel L. What is Wrong with Rational Suicide. Philosophia 2011; 39: 111.

2. Cholbi M. Suicide. In Zalta EN, (ed.) The Stanford Encyclopedia of Philosophy (Winter 2012 Edition), Available at http://plato.stanford.edu/archives/win2012/entries/suicide/ (Accessed 20th March 2013).

3. Devine P. On choosing death. In Battin M, Mayo D, (eds.) Suicide: The Philosophical Issues. New York: St. Martin's Press; 1980.

4. Mayo D. The concept of rational suicide. The Journal of Medicine and Philosophy 1986; 11: 150-152.

5. Kant, I. Metaphysics of Morals. Gregor M. trans. Cambridge: Cambridge University Press; 1996.

6. Cholbi M. Suicide Intervention and Non-ideal Kantian Theory. Journal of Applied Philosophy 2002; 19: 245-259.

7. Sellars J. Stoicism. Chesham: Acumen; 2006.

8. Wittgenstein L. Philosophical Investigations. Oxford: Basil Blackwell; 1984.

Received: March 27, 2013

Accepted: June 18, 2013 